\title{
A novel non-radioactive assay for HIV-RT (RdDp) based on pyrosequencing for high-throughput drug screening
}

\author{
Chang Zhang ${ }^{1}$, Yang Wu ${ }^{2}$, Yuna Sun ${ }^{2}$, Chuan Hong ${ }^{1}, K_{\text {Kehui Xiang }}{ }^{1}$, Yu Guo $^{3}$, Mark Bartlam ${ }^{3}$, Zhiyong Lou ${ }^{1 凶}$ \\ ${ }^{1}$ Tsinghua-Nankai-IBP Joint Research Group for Structural Biology, Tsinghua University, Beijing 100084, China \\ ${ }^{2}$ National Laboratory of Macromolecules, Institute of Biophysics, Chinese Academy of Sciences, Beijing 100101, China \\ ${ }^{3}$ College of Life Sciences and Tianjin State Laboratory of Protein Sciences, Nankai University, Tianjin 300071, China \\ \ Correspondence: louzy@xtal.tsinghua.edu.cn \\ Received January 4, 2010 Accepted January 15, 2010
}

\begin{abstract}
Current in vitro assays for the activity of HIV-RT (reverse transcriptase) require radio-labeled or chemically modified nucleotides to detect reaction products. However, these assays are inherently end-point measurements and labor intensive. Here we describe a novel non-radioactive assay based on the principle of pyrosequencing coupledenzyme system to monitor the activity of HIV-RT by indirectly measuring the release of pyrophosphate $\left(\mathrm{PP}_{\mathrm{i}}\right)$, which is generated during nascent strand synthesis. The results show that our assay could monitor HIV-RT activity with high sensitivity and is suitable for rapid highthroughput drug screening targeting anti-HIV therapies due to its high speed and convenience. Moreover, this assay can be used to measure primase activity in an easy and sensitive manner, which suggests that this novel approach could be wildly used to analyze the activity of $\mathrm{PP}_{\mathrm{i}}$-generated and ATP-free enzyme reactions.
\end{abstract}

KEYWORDS HIV-RT (RdDp), assay, non-radioactive, high throughput drug screening

\section{INTRODUCTION}

Human immunodeficiency virus (HIV) is a retrovirus that can lead to acquired immunodeficiency syndrome (AIDS), a condition in humans in which the immune system begins to fail, leading to life-threatening opportunistic infections. HIV type 1 (HIV-1) is a positive single-strand RNA virus and the genome encoded reverse transcriptase (RT) is essential for
HIV-1 replication. During replication, the RNA-dependent DNA polymerase (RdDp) transcribes single-stranded RNA into double-stranded DNA. Normal transcription involves the synthesis of RNA from DNA; hence, reverse transcription is the reverse of this. The RT converts single-stranded viral RNA into a linear double-stranded DNA, which can be integrated into host chromosomes (Sarafianos et al., 2004). HIV-1 RT is a heterodimer consisting of a 66-kDa (p66) and a 51-kDa (p51) subunit. With the exception of the last $120 \mathrm{C}$-terminal residues in $\mathrm{p} 66$, which form the $\mathrm{RNase} \mathrm{H}$ domain, these two polypeptide chains have the same $440 \mathrm{~N}$-terminal residues and can be divided into thumb, palm, fingers and connection (Kohlstaedt et al., 1992; Jacobo-Molina et al., 1993).

Due to the essential role in the viral life cycle and clear functional and structural investigation, HIV-RT has been the target of considerable interest for anti-viral drug development to date. In previous studies, a number of assays had been developed and applied to monitor HIV-RT RdDp activity in vitro for drug screening. Initial HIV-RT assays were based on the measurement of generated radioactive production by using radioactive compounds as the substrates. The most conventional method is to use ${ }^{3} \mathrm{H}$-labeled dTTP for in vitro HIV-RT assays (Hizi et al., 1993; Antoun et al., 1994; Kanyara and Njagi, 2005). However, the conventional isotopic HIV-RT assay is labor intensive and is becoming increasingly restrictive due to the use of radioactive materials. Although radioactive signals are easily detected and quantified, these assay systems inherently produce end-point measurements and kinetic evaluations are not easy to carry out. Bearing in mind the radioisotopic hazard, non-radioisotopic assays for measuring RT activity using mainly colorimetric methods have 
also been developed (Suzuki et al., 1993a, b). Briefly, BrdUTP is incorporated into a DNA strand complementary to the polyA template. Subsequently, an anti-BrdU antibody conjugated to alkaline phosphatase is added and the amount of incorporated BrdU detected using a substrate pNPP. The color intensity of each well is read using a standard plate reader ( $405 \mathrm{~nm}$, reference at $620 \mathrm{~nm}$ ) (Vassiliou et al., 2000). Several assays have been also established based on similar principles, but with variation in nucleotides modification and color developing methods (Porstmann et al., 1991; Urabe et al., 1992; Suzuki et al., 1993a, b; Odawara et al., 2002). Product-enhanced reverse transcriptase (PERT) assays were developed in order to increase the sensitivity. The principle of the PERT assay involves producing CDNA from template RNA by suspected RT in a test sample, amplifying the CDNA by polymerase chain reaction (PCR) and detecting the PCR amplicons by gel electrophoresis (Chang et al., 1997), Southern blotting (Silver et al., 1993), or an enzymelinked oligonucleotide sorbent assay (ELOSA) (Pyra et al., 1994; Andre et al., 2000). To further increase its sensitivity, the fluorescence PERT (F-PERT) assay and single-tube fluorescent product-enhanced reverse transcriptase (STFPERT) assay have been improved using real-time RT-PCR, with real-time detection of PCR product levels during amplification by using TaqMans PCR technology (Arnold et al., 1998; Lovatt et al., 1999). Though RT-PCR amplification FPERT and STF-PERT assay could be real-time and high sensitive, a real-time thermal cycler is still required and the speed of this assay could not perfectly fit high-throughput drug screening.

Recently, a new sensitive and continuous non-radioactive $\mathrm{RdRp}$ assay in which activity is measured based on the detection of pyrophosphate $\left(\mathrm{PP}_{\mathrm{i}}\right)$ has been reported (Lahser and Malcolm, 2004). Free $\mathrm{PP}_{\mathrm{i}}$ is released when the nucleotide

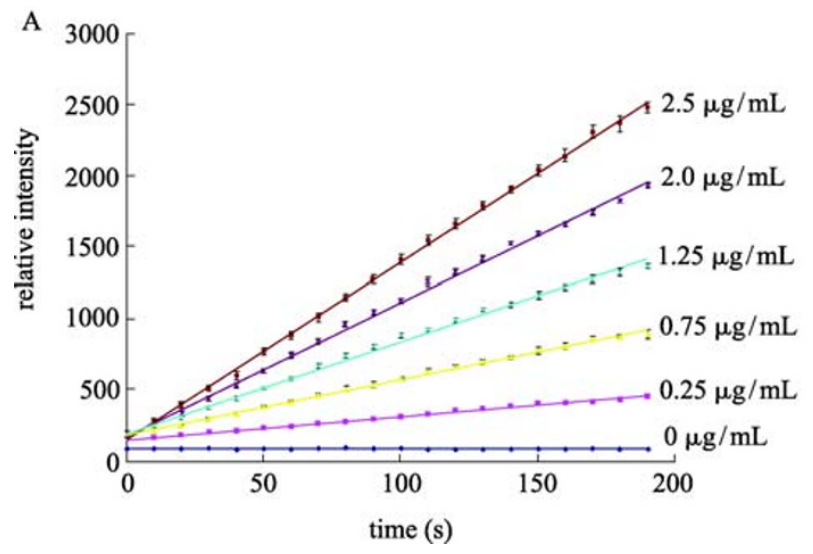

is incorporated onto the provided template. The $\mathrm{PP}_{\mathrm{i}}$ can then be detected by a coupled-enzyme system which can convert $\mathrm{PP}_{\mathrm{i}}$ to ATP and finally to a light signal. In comparison with the other non-radioactive assays described above, this assay has a competitive advantage in that native NTPs can be used. The coupled-enzyme system greatly amplifies the signal, thus allowing for the use of lower concentrations of enzyme, which is important in high-throughput inhibitor screening aiming at polymerase. Meanwhile, data in this assay are collected in real time, which makes the kinetic analysis of the whole reaction easy to assess.

Considering the similarity between $\mathrm{RdRp}$ and $\mathrm{RdDp}$, we applied the same approach to an HIV-1 RT in vitro activity assay. Our results show that this high-throughput method can measure HIV-RT activity easily and in real-time, suggesting that it is an effective assay and could potentially have significant impacts in high-throughput drug screening. Moreover, this assay could be used to measure primase activity easily and sensitively, which implies that this assay could be wildly used to monitor the activity of $\mathrm{PP}_{\mathrm{i}}$-generated and ATPfree enzyme reactions.

\section{RESULTS}

\section{Enzyme concentration}

The reaction was performed as indicated in "Materials and Methods". Signals were collected every $10 \mathrm{~s}$ with an integrated time of $100 \mathrm{~ms}$, then the real-time light intensity was recorded (Fig. 1A). As the assay can be considered as a pseudo-first order reaction, which can be described by $P=S_{0}\left(1-e^{-k t}\right)$, the initial stage of the reaction should simply follow the Taylor expansion $P=S_{0} k t$. We therefore used linear regression to determine the velocity. Data used for

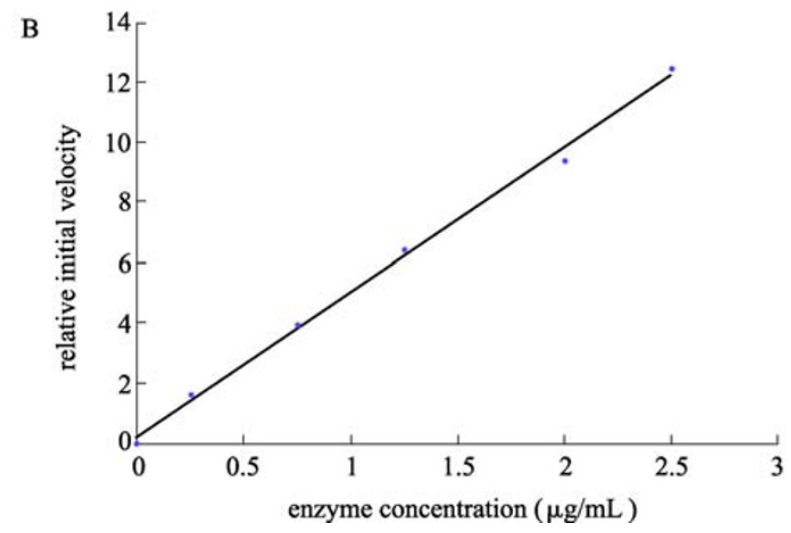

Figure 1. Effects of a series of HIV-RT concentrations. (A) Titration of HIV-RT. HIV-RT was serially diluted in storage buffer and assayed $(n=5)$ at room temperature with $2 \mu \mathrm{M}$ dTTP, $15 \mathrm{mU}$ ATP sulfurylase, and the poly A/oligo (dT) 18 in a 96-well plate with a final reaction volume of $100 \mathrm{~mL}$. Light was captured for $100 \mathrm{~ms}$ every $30 \mathrm{~s}$. Initial velocity values were derived from progress curve analyses, fitted by linear regression to the Taylor expansion of a simple first order model: $P=S_{0} k t$, where we apply $S_{0} k$ to evaluate the relative initial velocity. (B) Linearity of the reaction with HIV-RT concentration. Relative initial velocity estimates from the data in (A) were plotted against [HIV-RT]. Values were fitted by linear regression. 
initial velocity determination were corrected with a non-HIV$\mathrm{RT}$ control, and the reaction rate was linear with respect to enzyme concentration in the range tested (Fig. 1B).

\section{dTTP concentration}

The effects of dTTP concentration were evaluated in the reaction system. As indicated by Fig. $2 \mathrm{~A}$, the initial velocity was linear with respect to the concentration of dTTP in the range $2-10 \mu \mathrm{M}$ (Fig. 2B). A little inaccuracy was observed at low concentration and will be discussed in further detail below.

\section{Oligo (dT) 18 concentration}

As the primer of the first reaction, the effects of oligo (dT) 18 concentration were also investigated (Fig. 3A). Polymerase activity increased with primer concentration, with indications of saturation at the maximum concentration tested $(2 \mu \mathrm{g} / \mathrm{mL})$ (Fig. 3B).

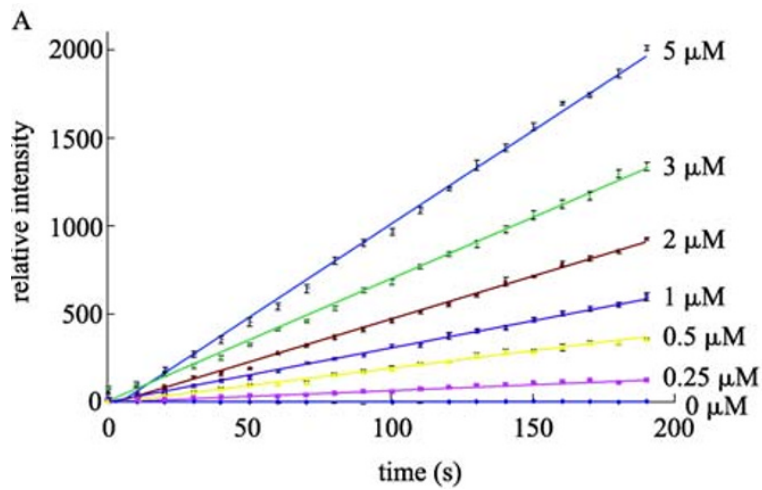

\section{Pre-incubation}

The impact of pre-incubation of HIV-RT with template (primer) was examined using the assay described above. HIV-RT was co-incubated with template (primer) prior to the initiation of RNA synthesis by addition of the remaining reaction components. As shown in Fig. 4, there is no obvious increase in signal within $3 \mathrm{~h}$ of pre-incubation. The results suggest that, for this system, formation of the initiation complex was not rate limiting, indicating that a good signal can be achieved without pre-incubation.

\section{Inhibition of HIV RT}

To demonstrate the utility of this assay for the evaluation of inhibitor, the commercial inhibitor nevirapine was applied to the assay. Different doses of nevirapine were introduced to the assay and compared with positive (HIV-RT+) and negative (HIV-RT-) controls. Signals were collected and initial

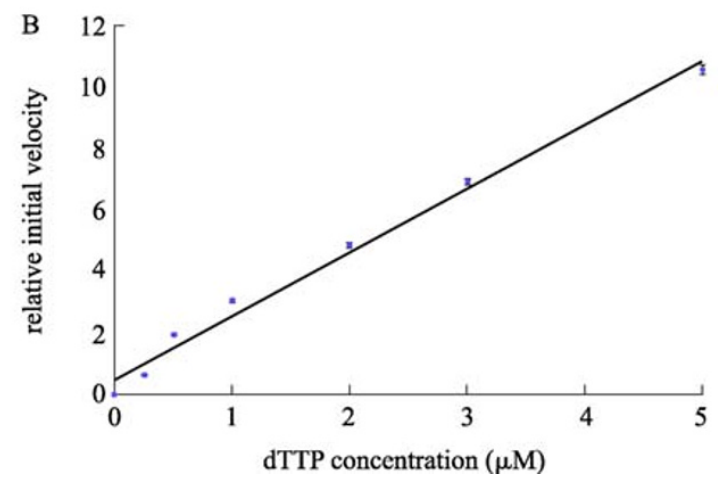

Figure 2. Effects of dTTP concentration on activity. (A) Various concentrations of dTTP were added; the HIV-RT concentration is 1.25 $\mu \mathrm{g} / \mathrm{mL}$; other conditions and parameters are as described for (Fig. 1A). Results shown are the average of 5 independent experiments $(n=$ 5). (B) Linearity of the reaction with dTTP concentration. Relative initial velocity estimates from data in (A) were plotted against [dTTP].
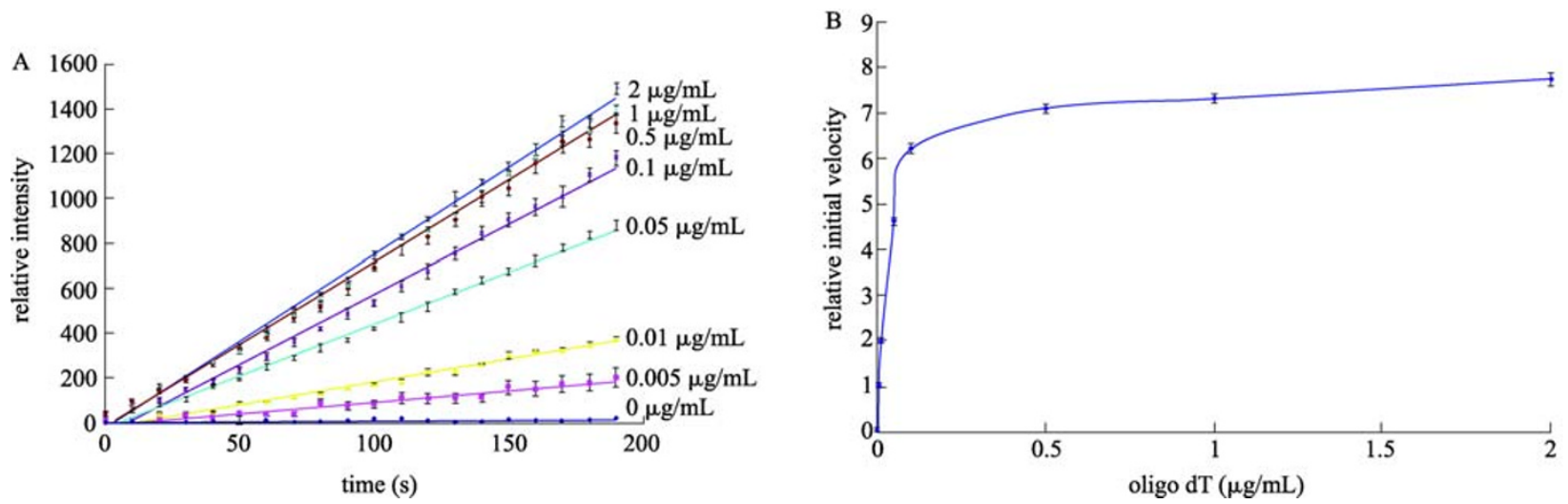

Figure 3. Effects of oligo (dT) 18 concentration on activity. (A) Various concentrations of oligo (dT) 18 were added; the HIV-RT concentration is $1.25 \mathrm{mg} / \mathrm{mL}$, other conditions and parameters are as described for Fig. $1 \mathrm{~A}$. Results shown are the average of 5 independent experiments $(n=5)$. (B) Polymerase activity increased with primer concentration, with indications of saturation at the maximum tested $(2 \mu \mathrm{g} / \mathrm{mL})$. 


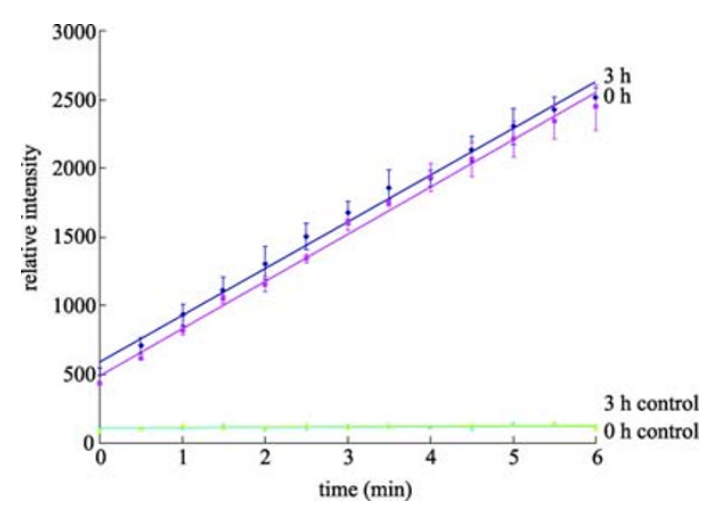

Figure 4. Pre-incubation of HIV-RT. HIV-RT was preincubated with polyA and oligo (dT) 18; the HIV-RT concentration is $1.25 \mathrm{mg} / \mathrm{mL}$, other conditions and parameters are as described for Fig. 1A. No obvious increase in signal was observed within $3 \mathrm{~h}$ of preincubation. Data were collected from three independent reactions $(n=3)$ for $0.1 \mathrm{~s}$ every $30 \mathrm{~s}$ during a 6 -min reaction.

velocities were calculated to evaluate the specific activity. Dose-dependent reduction in signal was observed for the nevirapine (Fig. 5).

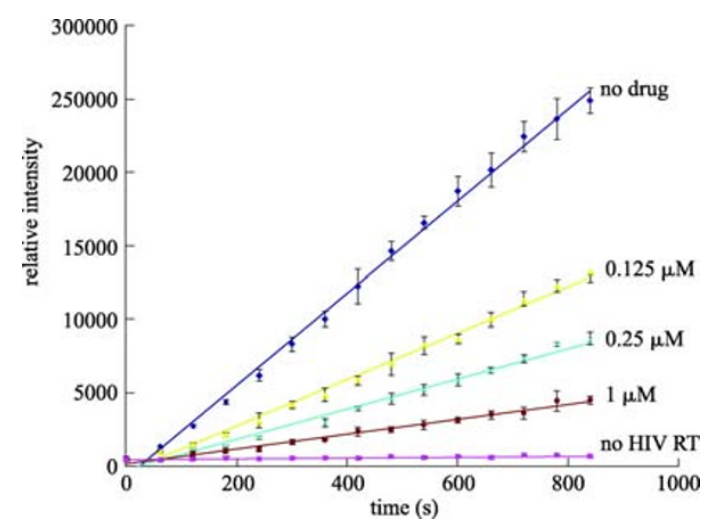

Figure 5. Inhibitor studies using nervirapine. (A) Inhibition of HIV-RT with varying concentrations of inhibitor nevirapine compare with positive (HIV-RT+) and negative (HIV-RT-) controls $(n=3)$. Reactions contained HIV-RT $(1.25 \mu \mathrm{g} / \mathrm{mL})$; other conditions and parameters are the same as described for Fig. $1 \mathrm{~A}$. Luminescence was measured for $0.1 \mathrm{~s}$ every $60 \mathrm{~s}$ during a 15 -min reaction.

\section{Comparison with colorimetric assay in sensitivity}

Analysis of a serial dilution of HIV-RT in low concentrations was done in comparison with a well accepted colorimetric assay to determine assay sensitivity. In this comparison, the same serial dilutions of recombinant HIV-RT were measured. As shown in Table 1, the detective sensitivity of $\mathrm{PP}_{\mathrm{i}}$ enzyme coupled assay is comparable with colorimetric assay in our experimental condition. The colorimetric assay can detect as low as $30 \mathrm{ng} / \mathrm{mL}$ recombinant HIV-RT after 90-min reaction time, while our data indicate PPi coupled enzyme assay can reach the equivalent sensitivity after only $15-$ min reaction time.

\section{DISCUSSION}

As mentioned above, the reliability of the assay relies in the fact that the components in the assay have to be carefully adjusted to ensure that the $\mathrm{PP}_{\mathrm{i}}$ generating reaction is the ratelimiting step. First, the substrate and enzyme in the lightgenerating cascade, such as APS, D-luciferin, ATP-sulfrylase and luciferase, must be sufficient to ensure that all the $\mathrm{PP}_{\mathrm{i}}$ generated by the HIV-RT can be converted into a light signal.

Second, the substrates required for $\mathrm{PP}_{\mathrm{i}}$ generation, such as polyA, oligo (dT) 18 and dTTP, should be in excess to ensure their concentrations remain nearly constant at the beginning of data collection, so that the initial velocity is solely dependent on the specific activity of HIV-RT. According to our experiments, the linear relationship between HIV-RT activity and initial velocity can be guaranteed at the concentrations of HIV-RT $(0-5 \mu \mathrm{g} / \mathrm{mL})$ and dTTP $(1-5 \mu \mathrm{M})$ tested, when sufficient oligo (dT) 18 is provided $(1 \mu \mathrm{g} / \mathrm{mL})$.

Signal-to-noise ratio is another issue that must be taken into consideration in this assay. As shown above, there is a little inaccuracy when the signal is collected at low dTTP concentration. The signal-to-noise ratio is not as good compared with that at high light intensity. To improve the signal-to-noise ratio at low concentration, the integration time can simply be extended to $0.2 \mathrm{~s}$ in order to enhance the light intensity. On the other hand, both the concentrations of HIVRT and dTTP can be increased properly to overcome this problem, but the velocity of the $\mathrm{PP}_{\mathrm{i}}$ generating reaction has to be limited to a range in which all of the accumulated $P P_{i}$ can be quickly converted to a light signal.

Comparing with the other assays such as F-PERT that has a better sensitivity, the $\mathrm{PP}_{\mathrm{i}}$-coupled enzyme assay has the advantage in convenience and time saving. Moreover, the sensitivity can be improved by simply increase the amount of the components if needed.

Our data clearly show that this assay is able to demonstrate the inhibition by nevirapine, which is a non-competitive inhibitor of HIV-RT. Nucleoside inhibitors of RT, i.e., the triphosphates of $A Z T$ or ddC, will release $\mathrm{PP}_{\mathrm{i}}$ as they are added in the chain termination reaction. Dose- and time-dependent reduction in signal was observed for the compound (Lahser and Malcolm, 2004), which is consistent with chain termination (i.e., once elongation is terminated by 3'-ddTTP incorporation, no further $\mathrm{PP}_{\mathrm{i}}$ can be produced). However, considering that we apply homopolymer (PolyA) rather than heteropolymer as a template, only deoxythymidine analogs (ddTTP, AZTTP etc.) can be evaluated. A special heteropolymer should be synthesized as a template to make better evaluation of all kinds of nucleoside inhibitors. 
Table 1 Comparison of colorimetric assay and $\mathrm{PP}_{\mathrm{i}}$ coupled enzyme assay

\begin{tabular}{|c|c|c|c|}
\hline \multirow[t]{3}{*}{ HIV RT $(\mu \mathrm{g} / \mathrm{mL})$} & \multicolumn{3}{|c|}{ relative value } \\
\hline & \multirow{2}{*}{$\begin{array}{c}\text { colorimetric assay } \\
\text { (absorbance } 450 \mathrm{~nm}) \\
90 \mathrm{~min}\end{array}$} & \multicolumn{2}{|c|}{$\begin{array}{c}\mathrm{PP}_{\mathrm{i}} \text { coupled enzyme assay } \\
\text { (light intensity) }\end{array}$} \\
\hline & & $15 \mathrm{~min}$ & $30 \mathrm{~min}$ \\
\hline 1 & $2.46325^{a}$ & $\mathrm{NT}^{\mathrm{b}}$ & NT \\
\hline 0.1 & 0.98075 & $2300.052^{c}$ & 4435.39 \\
\hline 0.03 & 0.4925 & 886.892 & 1505.82 \\
\hline 0.01 & 0.2475 & 496.812 & 662.996 \\
\hline 0.003 & 0.1895 & 444.566 & 539.364 \\
\hline 0.001 & 0.17575 & 333.866 & 374.84 \\
\hline 0 & 0.16175 & 276.398 & 366.984 \\
\hline cutoff value ${ }^{d}$ & 0.33 & 553 & 734 \\
\hline
\end{tabular}

In contrast to a similar assay adapted to monitor activity of the hepatitis $C$ virus nonstructural protein 5B (NS5B) RdRp (Lahser and Malcolm, 2004), our observations indicate that pre-incubation does not give rise to a significant increase in the signal. This would suggest that, for HIV-RT, formation of the initiation complex was not rate limiting, and that a good signal can be achieved without pre-incubation. Therefore, this is a robust time-saving method that can easily be adopted for high throughput screening.

Moreover, some other results show that this enzyme assay can be also easily applied to primase activity measurement (unpublished data), which just excluded primer from this assay and select suitable template and substrate. This result suggests that this pyro-sequencing-based enzyme assay could be not only applied to high-throughput drug screening aiming at HIV-RT, but also could be wildly used in investigations of ATP-free and $\mathrm{PP}_{\mathrm{i}}$-produced enzyme systems.

In summary, the coupled enzyme system used in pyrosequencing was adapted to evaluate the specific activity of HIVRT. The reaction system can provide reliable initial velocities at various enzyme and substrate concentrations in as little as 4 min compared to the assays described previously. This method can be easily performed in 96-well plates and signals can be rapidly collected in real time. These advantages ensure that the assay meets the demands of high-throughput anti-HIV-RT inhibitor screening.

\section{MATERIALS AND METHODS}

\section{Principle}

Pyro-sequencing is a method of DNA sequencing (determining the order of nucleotides in DNA) based on the "sequencing by synthesis" principle, which was innitially described by Ronaghi et al. (1998). This method relies on detecting the activity of DNA polymerase with a chemiluminescent enzyme. The single strand DNA (ssDNA) template is hybridized to a sequencing primer and incubated with four enzymes (DNA polymerase, ATP sulfurylase, luciferase and apyrase), and the substrates adenosine 5'-phosphosulfate (APS) and D-luciferin. Once the additional dNTPs (ATPaS instead of ATP) are added into this system, the DNA polymerase incorporates the correct, complementary dNTPs onto the template and releases $\mathrm{PP}_{\mathrm{i}}$ from each base pair. In the presence of APS, ATP sulfurylase coverts the released $P_{i}$ to ATP, which will help luciferase convert D-luciferin to oxyluciferin. This light, which was generated by oxyluciferin, will then be monitored by camera. The reaction steps proceed as follows:

$$
\begin{gathered}
(\mathrm{DNA})_{n}+\mathrm{dNTP} \underset{\text { DNA polymerase }}{\stackrel{(\text { slow })}{\longrightarrow}}(\mathrm{DNA})_{\mathrm{n}+1}+\mathrm{PPi}, \\
\text { APS }+ \text { PPi } \underset{\text { ATP sulfurylase }}{\stackrel{(\text { fast })}{\longrightarrow}} \text { ATP }+\mathrm{SO}_{4},
\end{gathered}
$$

and

D-luciferin $+\mathrm{ATP}+\mathrm{O}_{2} \underset{\text { luciferase }}{\stackrel{h v}{\longrightarrow}}$ oxyluciferin $+\mathrm{AMP}+\mathrm{PPi}+\mathrm{CO}_{2}$

As the net result of the last two steps does not consume any $\mathrm{PP}_{\mathrm{i}}$ produced by DNA polymerase, the polymerase activity can be easily evaluated by the $\mathrm{PP}_{\mathrm{i}}$ accumulation in the first step. On the other hand, from the last equation, it is evident that the light intensity is proportional to the $\mathrm{PP}_{\mathrm{i}}$ concentration in the reaction system. Thus the polymerase activity can be reasonable evaluated by the increase of light intensity.

As HIV-RT is a type of RdDp, it opens up the possibility that this system can be applied to monitor HIV-RT activity. In this system, HIVRT, polyA, oligodT and dTTP were respectively used as DNA polymerase, template, primer and dNTP in the pyrosequencing system. Since the template, primer and nucleotide are consistent in all reactions, the light signal increase should be only related with HIVRT activity in a unit time.

\section{Materials}

Chemical reagents for assay-related buffers were obtained from Sigma (St. Louis, MO). Purified firefly luciferase and D-luciferin were 
from Sigma. dTTP was purchased from Takara Bio Inc. Adenosine 5phosphosulfate (APS) and adenosine 5-triphosphate (ATP) sulfurylase $\left(1 \mathrm{U}\right.$ produces $1 \mu \mathrm{mol}$ of ATP from APS and $\mathrm{PP}_{\mathrm{i}}$ per min at $\mathrm{pH}$ 8.0 at $30^{\circ} \mathrm{C}$ ) were obtained from Sigma. The polyA homopolymer was from Sigma, and the oligo (dT) 18 was synthesized from Invitrogen. Nevirapine was a gift from Prof. Yiming Shao from the China Center for Disease Control and Prevention (CDC). White flat bottom polystyrene microplates (96-well) for the polymerase/luciferase assay were from Corning (Corning Co., USA). A microtiter plate luminometer (Luminoskan Ascent) was obtained from Thermo Scientific.

The express construct of HIV-1 RT was given by Prof. Eddy Arnold as a kindly gift. The protein of HIV-1RT was expressed and purified following the reported procedure (Clark et al., 1995). Briefly, the cells were sonicated by using lysis buffer, which contains $50 \mathrm{mM}$ sodium phosphate ( $\mathrm{pH}$ 8.0), $600 \mathrm{mM} \mathrm{NaCl}, 0.1 \%$ Triton X-100, $5 \mathrm{mM} \mathrm{BME,} 5$ $\mathrm{mM}$ Imidazole and $1 \mathrm{mM}$ PMSF. After being centrifuged at 18,000 rpm $30 \mathrm{~min}$, the supernatant was added into Ni-NTA column and target protein was eluted by $50 \mathrm{mM}$ sodium phosphate ( $\mathrm{pH} 8.0$ ), $200 \mathrm{mM}$ $\mathrm{NaCl}, 5 \mathrm{mM}$ BME, $250 \mathrm{mM}$ imidazole ( $\mathrm{pH}$ 8.0). Subsequently, the ionexchange column MonoQ was used to purify target protein. Enzyme stocks of the HIV-RT were prepared and stored in $10 \mathrm{mM}$ Tris- $\mathrm{HCl}(\mathrm{pH}$ 8.0), $75 \mathrm{mM} \mathrm{NaCl}$.

\section{Methods}

Polymerase assay

Polymerase assays were performed at room temperature using a $100 \mu \mathrm{L}$ reaction mix in a 96-well plate. Final reaction conditions for HIV-RT were $20 \mathrm{mM}$ Hepes (pH 7.5), $10 \mathrm{mM} \mathrm{MgCl}_{2}, 60 \mathrm{mM} \mathrm{NaCl}, 1$ $\mu \mathrm{g} / \mathrm{mL}$ oligo (dT) $18,5 \mu \mathrm{g} / \mathrm{mL}$ polyA, $2 \mu \mathrm{M}$ dTTP, and HIV-RT. The enzyme/template mixtures were supplemented with components for the ATP sulfurylase and luciferase coupled-enzyme reactions (310 $\mu \mathrm{M}$ D-luciferin, $1 \mathrm{nM}$ luciferase, $10 \mu \mathrm{M}$ APS, $15 \mathrm{mU}$ ATP sulfurylase).

Ninty-six-well microtiter plates containing $50 \mu \mathrm{L}$ initiated enzyme/ template mix were supplemented with substrate mix by multi-channel pipette, then the plate was immediately transferred to the luminometer (Thermo Scientific) for detection of the light signal in real time (using the instrument's "kinetic" programme). A $0.1 \mathrm{~s}$ reading of each well was taken every $10 \mathrm{~s}$ (at least $20 \mathrm{~s}$ is needed if all the 96 wells are tested). All of the light signals collected were compared with corresponding non-HIV-RT controls. Data used for initial velocity calculations were restricted to the first $200 \mathrm{~s}$ to avoid the influence of substrate depletion and/or product inhibition.

The key point of the assay is to ensure that the generation of $\mathrm{PP}_{\mathrm{i}}$, i.e., the first reaction, is rate limiting. To ensure that, both enzymes and substrates should be carefully evaluated during the reaction. According to the above principle, the initial velocity should depend completely on the first reaction when the components in the light generating cascade are fixed and sufficient. Furthermore, the substrates in the $\mathrm{PP}_{\mathrm{i}}$ generating reaction must be in excess to ensure linearity at the beginning of data collection. Thus, the effects of both the enzyme and substrates in the first step reaction were evaluated so that proper concentrations can be determined to guarantee the linear relation between HIV-RT activity and light intensity.

To determine whether the reaction system was reliable for evaluation of the specific activity of HIV-RT, a series of enzyme concentrations were applied to monitor the relationship between the specific activity and the initial velocity.
To test the effects of dTTP on the initial velocity, various dTTP diluents were introduced to the assay. Reactions were performed as described above, with different dTTP concentration in the substrate mixture.

To assess the effects of the oligo (dT) 18 on the initial velocity so that a proper concentration can be determined, a series of oligo (dT) 18 concentrations were used to get a saturated concentration.

The effects of pre-incubation were assessed by combining (at 0-3 h) HIV-RT, polyA, and oligo (dT) 18 at twice the final reaction concentration and initiated by addition of an equal volume of a $2 \times$ reaction mix containing luciferase, ATP sulfurylase, dTTP, APS, and D-luciferin. Data were collected for 6 min.

To demonstrate the utility of this assay for the evaluation of HIV-RT inhibitors, it was applied to the commercial inhibitor nevirapine.

Comparison with colorimetric assay in sensitivity

To further demonstrate the validity and the sensitivity of the assay, analysis of a dilution series of HIV RT was done compare with a widely accepted colorimetric RT assay (Urabe et al., 1992).

Poly A-linked colorimetric RT assay was performed using the method described before (Suzuki et al., 1995) with slight modifications. Briefly, wells were prepared prior to the assay by $50 \mu \mathrm{L}$ of 1.875 $\mu \mathrm{g} / \mathrm{mL}$ poly A (Sigma) in $0.95 \mathrm{mM} \mathrm{N}$-hydroxysulfosuccinimide (NHSS) (Shanghai Medpep Co., Ltd.) to $50 \mu \mathrm{L}$ of $3.0 \mathrm{mM}$ 1-ethyl-3-(3dimethylaminopropyl) carbodiimide (EDC) (Shanghai Medpep Co., Ltd.) per microtiter well (Covalink from Nunc), incubating for 14-18 h at room temperature and then storing at $4^{\circ} \mathrm{C}$. Wells were washed 3 times with washing buffer (10 mM Tris- $\mathrm{HCl}, \mathrm{pH} 7.5,150 \mathrm{mM} \mathrm{NaCl}, 1$ mM EDTA, 0.01\% Tween-20) just prior to use. Enzyme activity was measured by adding $10 \mu \mathrm{L}$ RT to $50 \mu \mathrm{L}$ of reaction buffer ( $50 \mathrm{mM}$ Tris$\mathrm{HCl}, \mathrm{pH} 8.0,6 \mathrm{mM} \mathrm{MgCl}_{2}, 75 \mathrm{mM} \mathrm{KCl}, 5 \mathrm{mM}$ DTT, $1 \mathrm{mg} / \mathrm{mL}$ BSA, $0.3125 \mu \mathrm{g} / \mathrm{mL}$ oligo (dT) 15 (Invitrogen), $0.52 \mu \mathrm{M}$ dTTP (Takara), 0.26 $\mu \mathrm{M}$ Biotin-11-dUTP (Shanghai Mol-Immuno Biochemistry Lab)), in microtiter wells. The reactions were incubated at room temperature for $1.5 \mathrm{~h}$ and then washed with wash buffer. After washing, $100 \mu \mathrm{L}$ of streptavidin phosphatase (SAP) $\left(\mathrm{KPL}^{\mathrm{TM}}\right) 0.5 \mathrm{mg} / \mathrm{mL}$ diluted $1: 1000 \mathrm{in}$ PBS buffer with $1 \%$ BSA was added to each well. The plate was incubated for $30 \mathrm{~min}$ at $37^{\circ} \mathrm{C}$. Free conjugate was removed by washing 6 times with washing buffer. As a final step, $200 \mu \mathrm{L}$ 4-nitrophenyl phosphate disodium salt hexahydrate (pNPP) (Fluka) $1 \mathrm{mM}$ in pNPP buffer ( $1 \mathrm{mM} \mathrm{MgCl}_{2}, 100 \mathrm{mM}$ Bicine, $\mathrm{pH}$ 9.8) was added to each well, the plate was incubated at room temperature for 5-10 min and then read at $450 \mathrm{~nm}$ with a plate reader (Dynatech).

$\mathrm{PP}_{\mathrm{i}}$ coupled enzyme assay was performed as described before.

\section{ACKNOWLEDGEMENTS}

We thank Prof. Yiming Shao (China CDC) for providing the HIV-RT inhibitor nevirapine.

This project was supported by the National Natural Science Foundation of China (Grant Nos. 30221003, 30720022), the Ministry of Science and Technology 973 Project (Grant No. 2006CB806503), the Ministry of Science and Technology National High Technology Research and Development Program ("863" Program) (Grant No. 2006AA02A322), the Ministry of Science and Technology International Cooperation Project (Grant No. 2006DFB32420), and the Chinese Academy of Sciences Knowledge Innovation Project (Grant No. KSCX1-YW-R-05). 


\section{ABBREVIATIONS}

APS, adenosine 5'-phosphosulfate; ATP, adenosine 5-triphosphate; BrdUTP, bromodeoxyuridine triphosphate; ELOSA, enzyme-linked oligonucleotide sorbent assay; F-PERT, fluorescence PERT; HIV-RT, human immunodeficiency virus reverse transcriptase; $P E R T$, product enhanced reverse transcriptase; pNPP, p-nitrophenyl phosphate; $P P_{i}$, pyrophosphate; RdDp, RNA-dependent DNA polymerase; SA-ALP, streptavidin-alkaline phosphatase; STF-PERT, single-tube fluorescent PERT

\section{REFERENCES}

Andre, M., Morgeaux, S., and Fuchs, F. (2000). Quantitative detection of RT activity by PERT assay: feasibility and limits to a standardized screening assay for human vaccines. Biologicals 28, 67-80.

Antoun, M.D., Rios, Y.R., Mendoza, N.T., and Proctor, G. (1994). Reverse transcriptase inhibition as prescreen for potential antiviral bioactives. P R Health Sci J 13, 17-18.

Arnold, B.A., Hepler, R.W., and Keller, P.M. (1998). One-step fluorescent probe product-enhanced reverse transcriptase assay. Biotechniques 25, 98-106.

Chang, A., Ostrove, J.M., and Bird, R.E. (1997). Development of an improved product enhanced reverse transcriptase assay. J Virol Methods 65, 45-54.

Clark, A.D., Jr., Jacobo-Molina, A., Clark, P., Hughes, S.H., and Arnold, E. (1995). Crystallization of human immunodeficiency virus type 1 reverse transcriptase with and without nucleic acid substrates, inhibitors, and an antibody Fab fragment. Methods Enzymol 262, 171-185.

Hizi, A., Tal, R., Shaharabany, M., Currens, M.J., Boyd, M.R., Hughes, S.H., and McMahon, J.B. (1993). Specific inhibition of the reverse transcriptase of human immunodeficiency virus type 1 and the chimeric enzymes of human immunodeficiency virus type 1 and type 2 by nonnucleoside inhibitors. Antimicrob Agents Chemother 37, 1037-1042.

Jacobo-Molina, A., Ding, J., Nanni, R.G., Clark, A.D., Jr., Lu, X., Tantillo, C., Williams, R.L., Kamer, G., Ferris, A.L., Clark, P., et al. (1993). Crystal structure of human immunodeficiency virus type 1 reverse transcriptase complexed with double-stranded DNA at 3.0 A resolution shows bent DNA. Proc Natl Acad Sci U S A 90, 6320-6324.

Kanyara, J.N., and Njagi, E.N. (2005). Anti-HIV-1 activities in extracts from some medicinal plants as assessed in an in vitro biochemical HIV-1 reverse transcriptase assay. Phytother Res 19, 287-290.

Kohlstaedt, L.A., Wang, J., Friedman, J.M., Rice, P.A., and Steitz, T.A. (1992). Crystal structure at 3.5 A resolution of HIV-1 reverse transcriptase complexed with an inhibitor. Science 256, 1783-1790.
Lahser, F.C., and Malcolm, B.A. (2004). A continuous nonradioactive assay for RNA-dependent RNA polymerase activity. Anal Biochem 325, 247-254.

Lovatt, A., Black, J., Galbraith, D., Doherty, I., Moran, M.W., Shepherd, A.J., Griffen, A., Bailey, A., Wilson, N., and Smith, K.T. (1999). High throughput detection of retrovirus-associated reverse transcriptase using an improved fluorescent product enhanced reverse transcriptase assay and its comparison to conventional detection methods. J Virol Methods 82, 185-200.

Odawara, F., Abe, H., Kohno, T., Nagai-Fujii, Y., Arai, K., Imamura, S., Misaki, H., Azuma, H., Ikebuchi, K., Ikeda, H., et al. (2002). A highly sensitive chemiluminescent reverse transcriptase assay for human immunodeficiency virus. J Virol Methods 106, 115-124.

Porstmann, T., Meissner, K., Glaser, R., Dopel, S.H., and Sydow, G. (1991). A sensitive non-isotopic assay specific for HIV-1 associated reverse transcriptase. J Virol Methods 31, 181-188.

Pyra, H., Boni, J., and Schupbach, J. (1994). Ultrasensitive retrovirus detection by a reverse transcriptase assay based on product enhancement. Proc Natl Acad Sci U S A 91, 1544-1548.

Ronaghi, M., Uhlen, M., and Nyren, P. (1998). A sequencing method based on real-time pyrophosphate. Science 281, 363-365.

Sarafianos, S.G., Das, K., Hughes, S.H., and Arnold, E. (2004). Taking aim at a moving target: designing drugs to inhibit drugresistant HIV-1 reverse transcriptases. Curr Opin Struct Biol 14, 716-730.

Silver, J., Maudru, T., Fujita, K., and Repaske, R. (1993). An RT-PCR assay for the enzyme activity of reverse transcriptase capable of detecting single virions. Nucleic Acids Res 21, 3593-3594.

Suzuki, K., Craddock, B.P., Kano, T., and Steigbigel, R.T. (1993a). Colorimetric reverse transcriptase assay for HIV-1. J Virol Methods $41,21-28$.

Suzuki, K., Craddock, B.P., Okamoto, N., Kano, T., and Steigbigel, R. T. (1993b). Detection of human immunodeficiency virus (HIV) by colorimetric assay for reverse transcriptase activity on magnetic beads. Biotechnol Appl Biochem 18 ( Pt 1), 37-44.

Suzuki, K., Saito, T., Kondo, M., Osanai, M., Watanabe, S., Kano, T., Kano, K., and Imai, M. (1995). Poly A-linked non-isotopic microtiter plate reverse transcriptase assay for sensitive detection of clinical human immunodeficiency virus isolates. J Virol Methods 55, 347-356.

Urabe, T., Sano, K., Tanno, M., Mizoguchi, J., Otani, M., Lee, M.H., Takasaki, T., Kusakabe, H., Imagawa, D.T., and Nakai, M. (1992). A non-radioisotopic reverse transcriptase assay using biotin-11deoxyuridinetriphosphate on primer-immobilized microtiter plates. J Virol Methods 40, 145-154.

Vassiliou, W., Epp, J.B., Wang, B.B., Del Vecchio, A.M., Widlanski, T., and Kao, C.C. (2000). Exploiting polymerase promiscuity: A simple colorimetric RNA polymerase assay. Virology 274, 429-437. 